\title{
The possible radioprotective effects of vitamin $E$, Nigella sativa oil, and melatonin against $X$-ray induced early acute changes in cerebral and cerebellar cortices in Albino rats: Histological and Immunohistochemical
}

\author{
Eman K. Nor-Eldin and Hoda M. Elsayed
}

Histology Department, Faculty of Medicine, Sohag University, Egypt

\begin{abstract}
Background: Radiation induced brain and cerebellum injury is common in patients receiving radiotherapy for head and neck tumors. Administration of antioxidants before radiation as vitamin E, nigella sativa oil and melatonin could be valuable in limiting this injury.

Material and Methods: 40 rats were divided into five different groups. Group I: served as the control group and subdivided into 4subgroups. subroup Ia: negative control, subgroup Ib: animals received vitamin E only ( $300 \mathrm{mg} / \mathrm{kg}$ orally once, subgroup Ic: animals received nigella sativa oil only ( $1 \mathrm{ml} / \mathrm{kg}$ orally once and subgroup Id: animals received melatonin only $100 \mathrm{mg} /$ kg intraperitoneally once: Group II: animals were exposed to x ray irradiation (XRI) (8 Gy whole body). Group III: animals were pretreated with vitamin E $(300 \mathrm{mg} / \mathrm{kg}$ orally once $1 \mathrm{~h}$ before XRI. Group IV: animals were pretreated with nigella sativa oil $(1 \mathrm{ml} / \mathrm{kg}$ orally once $1 \mathrm{~h}$ before XRI). Group V: animals were pretreated with melatonin $(100 \mathrm{mg} / \mathrm{kg}$ intraperitoneally once $1 \mathrm{~h}$ before XRI). Animals were sacrificed $48 \mathrm{~h}$ after irradiation. Brain and cerebellum were dissected, formalin fixed and processed for histological and glial fibrillary acidic protein (GFAP) immunostainig. The number of GFAP positive astrocytes were counted and statistically analyzed using SPSS program.

Results: Radiation induced loss of lamellar pattern in the cerebral cortex with degeneration and necrosis of cortical nerve cells. In the cerebellum, purkinje cell degeneration was observed. Radiation induced a significant increase in the number of GFAP positive astrocytes in both cerebral and cererbellar cortices compared to the control group. In groups treated with vitamin E, nigella sativa oil and melatonin, there was partial improvement in cerebral and cerebellar changes with a significant decrease in the number of GFAP positive astrocytes.

Conclusion: The use of antioxidants such as vitamin E, nigella and melatonin could limit radiation induced injury in brain and cerebellum.
\end{abstract}

Received: 26 March 2019, Accepted: 10 April 2019

Key Words: GFAP, melatonin, nigella, radiation.

Corresponding Author: Hoda Mohammed Elsayed, MD, Histology Department, Faculty of Medicine, Sohag University, Sohag, Egypt, Tel.: +20 1093882036, E-mail: hoda_abdelrasowl@med.sohag.edu.eg

ISSN: 1110-0559, Vol. 42, No. 4

\section{INTRODUCTION}

Cranial radiation is an essential therapeutic tool in the treatment of primary and secondary brain tumors. It has adverse effects including cognitive dysfunction which can affect the quality of life ${ }^{[1,2]}$

The response of the normal tissues to therapeutic radiation can range from mild discomfort to life threatening effects. The rate of these responses depends on the amount and distribution of the dose of radiation received by tissues ${ }^{[3,4]}$. Radiation toxicity was reported to be mediated by the mechanism of free radical injury of tissues thereby causing oxidative damage. Antioxidants can reduce the toxicity associated with radiation damage as free radical scavengers ${ }^{[5,6]}$.

Nigella sativa is a plant of the Ranunculaceae spp. family that grows spontaneously and widely in several southern Mediterranean and Middle Eastern countries. Its seed has over 100 different chemical constituents, including abundant sources of all the essential fatty acids ${ }^{[7]}$.

It has many pharmacological effects such as antioxidative $^{[8]}$, immunomodulation ${ }^{[9]}$, anti-inflammatory, neuroprotective, anti-ischemic, antiepileptic and anxiolytic ${ }^{[10,11]}$. Many of the pharmacological activities mentioned above have been attributed to quinone constituents in the seed, especially thymoquinone ${ }^{[12]}$. Ahlatci et al. 2014 reported the significant radiationmodifying abilities of Nigella sativa and thymoquinone on the brain tissue ${ }^{[13]}$.

Vitamin $\mathrm{E}$ is a natural component of cell membranes and is considered the main defense against membrane lipid peroxidation. There are several types of tocopherol, $\alpha$-tocopherol being more reactive and with stronger antioxidant power. It reacts quickly with peroxyl free 
radicals interrupting the free radical chain reaction and consequently protecting cells from damage. Many researches upon the radioprotective effects of vitamin $\mathrm{E}$ have been reported, such as preservation of the small bowel crypt, increase in the rate of DNA repair process, salivary dysfunction $^{[14]}$, against mutagenic and/or carcinogenic agents in animals and cell cultures, and a reduction in the number of micronuclei in human lymphocytes in vitro ${ }^{[15]}$.

Melatonin is an endogenous hormone secreted by the pineal gland characterized by its small size and high lipophilicity. It can cross the blood brain barrier and distributes throughout the cells ${ }^{[16]}$. It is reported that melatonin decreased the radiation-induced parotid and submandibular histological damage as well as decreased the oxidative stress markers ${ }^{[17]}$. Elmissiry et al reported the ameliorative effect of melatonin in radiation induced liver damage by decreasing the liver enzymes levels and the oxidative stress markers ${ }^{[18]}$.

\section{AIM OF OUR WORK}

To study the possibility of the protective effect of vitamin E, Nigella sativa and melatonin on radiation induced brain and cerebellar damage in acute exposure if they are taken before irradiation and to assess the role of astrocyte in these changes.

\section{MATERIAL AND METHODS}

\section{Materials}

Vitamin E capsules ( $400 \mathrm{mg}$ ) and nigella sativa oil were obtained from PHARCO Pharmaceuticals (Cairo, Egypt).

Melatonin (sigma, St. Louis, MO, USA).

\section{Animals}

Three month old Albino rats were obtained from Assuit University Animal Facility, Faculty of Medicine, Egypt. They were housed in Animal Facility at Faculty of Medicine, Sohag University, Egypt. All rats were given access for rodent chow diet and water. This study was carried out in accordance with the guidelines of the University Animal Ethics and approved by Research Ethics Committee considering care and use of laboratory animals.

\section{Experimental design}

After a 7-day acclimatization period, 40 rats were divided into 5 different groups as following.

Group I: included 20 rats subdivided into the following 4 subgroups 5 rats each as following:

subgroup Ia: served as the negative control group.

subgroup Ib: animals were treated with vitamin $\mathrm{E}$ only $300 \mathrm{mg} / \mathrm{kg}$ once orally via gastric tube.

subgroup Ic: animals were treated with nigella sativa oil only $1 \mathrm{ml} / \mathrm{kg}$ once orally via gastric tube

subgroup Id: animals were treated with melatonin 100 $\mathrm{mg} / \mathrm{kg}$ once intraperitoneally.
Group II: included 5 animals that were exposed to $x$ ray irradiation (XRI) (8 Gy whole body $)^{[19]}$.

Group III: included 5animals that were pretreated with vitamin $\mathrm{E}(300 \mathrm{mg} / \mathrm{kg} \text { orally once } 1 \mathrm{~h} \text { before XRI })^{[20]}$.

Group IV: included 5 animals that were pretreated with nigella sativa oil $(1 \mathrm{ml} / \mathrm{kg} \text { orally once } 1 \mathrm{~h} \text { before XRI })^{[21]}$.

Group V: included 5 animals that were pretreated with melatonin $(100 \mathrm{mg} / \mathrm{kg}$ intraperitoneally once $1 \mathrm{~h}$ before irradiation $)^{[19]}$. Freshly prepared in $1000 \mathrm{ml}$ of $5 \%$ ethanol (made with phosphate-buffered saline).

\section{X-ray irradiation}

X-ray irradiation was carried out at The Department of Radiology and Oncology, Sohag University Hospitals, Egypt using a linear accelerator (Philips SL75.5). This device was adjusted to provide $\mathrm{X}$-ray but not gamma irradiation, and therefore, no filters were used in these experiments. Each animal was placed separately in a special small box with adjustable width that can fairly accommodate the animal without allowing any movements. Each animal was exposed to a whole-body XRI dose of 8 Grays (Gy). The dose was delivered at a rate of 400 motor unit/minute. The XRI dose for the brain was measured using special equation, and it was $8 \mathrm{~Gy} / \mathrm{brain}$.

\section{Methods}

The animals were sacrificed $48 \mathrm{~h}$ after $\mathrm{XRI}^{[19]}$ Brain and cerebellum were dissected, formalin fixed and processed for the following:

1. Histological examination by $\mathrm{H}$ and $\mathrm{E}$

2. Immunohistochemical study:

Paraffin sections of 4um thickness were immunostained using peroxidase-labelled streptavidin-biotin technique to detect glial fibrillary acidic protein (GFAP) in astrocytes. This stain is considered specific for the intermediate filaments fibrillary acidic protein which is found in astrocytes and not found in nerve cells and even other types of glial cells as oligodendroglia or microglia.

Staining procedure: Formalin-fixed, paraffin-embedded tissue sections were done and mounted on coated glass slides. Sections were deparaffinized and rehydrated through descending grades of alcohols $(100 \%, 90 \%, 80 \%$ and $70 \%$ ) then put in distilled water for $5 \mathrm{~min}$. Endogenous peroxidase activity was blocked with $0.6 \%$ hydrogen peroxide for 10 minutes using peroxidase blocking reagent. Antigenretrieval was done by boiling slides in citrate buffer solution ( $\mathrm{pH}$ 6.0). The slides were microwaved at a high medium for $10 \mathrm{~min}$. The sections were incubated with $1 / 50$ of anti GFAP antibody at $4^{\circ} \mathrm{C}$ for $18-20 \mathrm{~h}$, washed and incubated with biotinylated secondary antibodies, and then with the avidin-biotin complex. Finally, sections were counterstained with hematoxylin, dehydrated, cleared, and mounted. GFAP-positive cells appeared brown and nuclei appeared blue. Negative control sections was done with omission of the 1ry (anti GFAP) antibody. Universal 
kits and primary antibody (anti GFAP antibody) were purchased from Thermo fisher scientific company.

\section{Morphometric and Statistical Analysis}

The number of GFAP-positive cells was counted per 5 high power fields $(\mathrm{x} 400)$ in slides from each animal in each group using (CX21, Japan. Light microscope) in Histology Department, Faculty of Medicine, Sohag University. For statistical analysis ANOVA test was performed to compare the mean number of GFAP positive cells between the different groups followed by posthoc test. $P$ value was considered significant when it is $\leq 0.05$.

\section{RESULTS}

\section{Cerebral Cortex}

\section{Histological Structure}

Examination of H\&E stained sections form positive and negative control groups revealed no morphological differences. The cerebral hemisphere of the control rat consisted of an outer cortex of gray matter and a subcortical region of white matter. The cortex contained neurons, glial cells and nerve fibers. The organization of neurons in the cerebral cortex appeared as six layers; the molecular layer (fibrous with few nerve cell bodies), the external granular layer, the external pyramidal cell layer, the internal granular layer, the internal pyramidal cell layer and the multiform cell layer (Figure 1). The neuropil contained neuroglia, nerve fibers and blood vessels with a narrow perivascular space. Cortical neurons had rounded vesicular nuclei with prominent nucleoli, slight basophilic cytoplasm and peripheral processes (Figure 2). Examination of cerebral cortex of irradiated animals revealed dilated perivascular space with loss of lamellar pattern and damaged meninges. They are patches of pale areas in between nerve cells (cerebral necrosis), with degenerated nerve cells which appeared shrunken with pyknotic nuclei, deeply stained cytoplasm and increased perineural space (Figures $3 \& 4$ ).

Examination of cerebral cortex of irradiated animals pretreated with Vitamin E revealed, return of the lamellar pattern as control group with intact meninges. Nerve cells appeared more or less as control group. others showed degeneration. cells appeared shrunken with pyknotic nuclei, deeply stained cytoplasm and increased perineural space (Figures 5\&6).

Examination of sections from irradiated rat's cerebral cortex pretreated with Nigella revealed, some nerve cells appeared more or less as the control. Others appeared degenerated with pyknotic nuclei and deeply stained cytoplasm (Figures $7 \& 8$ ).

Examination of Melatonin pretreated irradiated group revealed that some nerve cells are degenerated leaving empty spaces while others were similar to the control. There was mild blood vessels dilatation under meninges (Figures 9 \&10).

\section{Immunohistochemical and Morphometric Study}

Immunohistochemical staining for GFAP revealed positive staining in the form of brown coloration in the cytoplasm of astrocytes and their processes. They appeared small with few short, thin processes. (Figure 11). Examination of irradiated rat's cerebral cortex revealed a significant increase in the number of astrocytes compared to the control group with thick long processes (Figure 12, Table 1, Histogram 1). Examination of irradiated rat's cerebral cortex pretreated with vitamin E revealed a a significant decrease in the number of astrocytes compared to the previous group with abundant many process (Figure 13, Table 1, Histogram 2). Examination of the Nigella pretreated irradiated group showed a significant decrease in the number of astrocyte with localized distribution compared to the irradiated group (Figure 14, Table 1, Histogram 1). With examination of irradiated rat's cerebral cortex pretreated with melatonin immunostained with GFAP, showed a significant decrease in the number of astrocytes compared to the irradiated group (Figure 15, Table 1, Histogram 1).

\section{Cerebellar cortex}

\section{1-Histological structure}

Examination of the control rat cerebellar cortex revealed that the cortex formed of three layers;molecular layer which contained few cells. Purkinje cell layer with their rounded vesicular nucleus and basophilic cytoplasm and basophilic granules (Nissel bodies) and granular cell layer which had numerous densely packed cells (Figure 16).

With examination of irradiated rat cerebellar cortex, It showed mild dissociation of Purkinje cell layer and molecular layer. Some Purkinje cells had vacuolated cytoplasm other cells were shrunken with deeply stained cytoplasm. The granular cell layer and molecular layer were more or less as the control group (Figure 17). An examination of irradiated rat cerebellar cortex pretreated with Vitamin E revealed degenerated Purkinje cells with vacuolated cytoplasm, other cells were shrunken with deeply stained cytoplasm. The granular cell layer and molecular layer were more or less as the control group (Figure 18). The irradiated rat cerebellar cortex pretreated with Nigella, examination showed some Purkinje cells were degenerated, others were more or less as the control group. The granular cell layer and molecular layer were more or less as the control group (Figure 19). An examination of cerebellar cortex of rats treated with melatonin demonstrates that some Purkinje cells were degenerated, other cells had deeply stained small nuclei. Granular cell layer and molecular layer were more or less as the control group (Figure 20).

\section{2-Immunohistochemical and Morphometric Study}

Examination of control rat cerebellar cortex demonstrates that immunoreactive astrocytes had brown 
coloration of the bodies and their long thick processes in molecular layer. Few astrocytes with few and thick processes in the granular and pukinje layer also had brown positive reaction(Figure 21).

With examination of irradiated rat's cerebellar cortex, it showed a significant increase in the number of astrocytes with apparent increase their intensity for staining in the molecular layer compared to the control groupin molecular layer. There was a significant increase in the number of astrocytes with increase their intensity for staining in the granular cell layer compared to the control group (Figure 22, Table 2, Histogram 2).

The irradiated rat's cerebellar cortex pretreated with vitamin $\mathrm{E}$, on examination revealed that, the astrocyte number was significantly decreased compared to the irradiated one with apparent decrease in the intensity of staining (Figure 23, Table 2, Histogram 2).

Examination of irradiated rat's cerebellar cortex pretreated with Nigella demonstrated a significant decrease in the number of astrocytes compared to the irradiated group (Figure 24, Table 2, Histogram 2).

Examination of irradiated rat's cerebellar cortex pretreated with Melatonin revealed a significant decrease in the number of astrocytes in molecular, purkinje cell and granular cell layers intensity and number are less than the irradiated one (Figure 25, Table 2, Histogram 2).

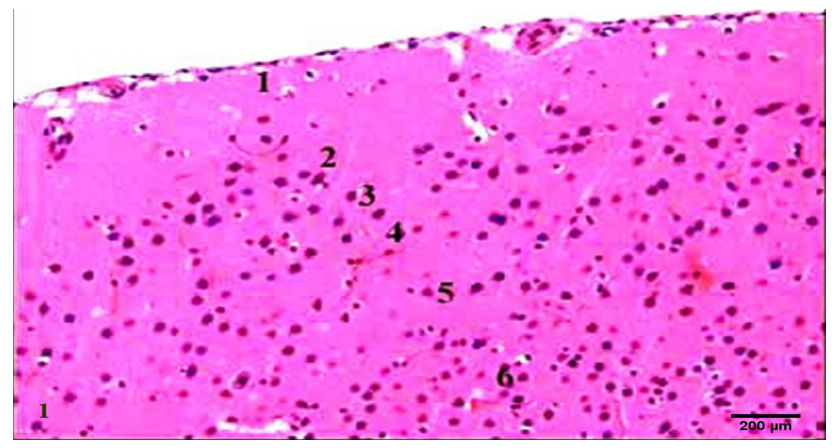

Fig. 1: A photomicrograph of a section from a control rat's cerebral cortex showing the six layers, which are clearly defined as: molecular (1), external granular (2), external pyramidal (3), internal granular (4), internal pyramidal (5), and multiform, which is the deepest layer (6). ( Group I H\&Ex200)

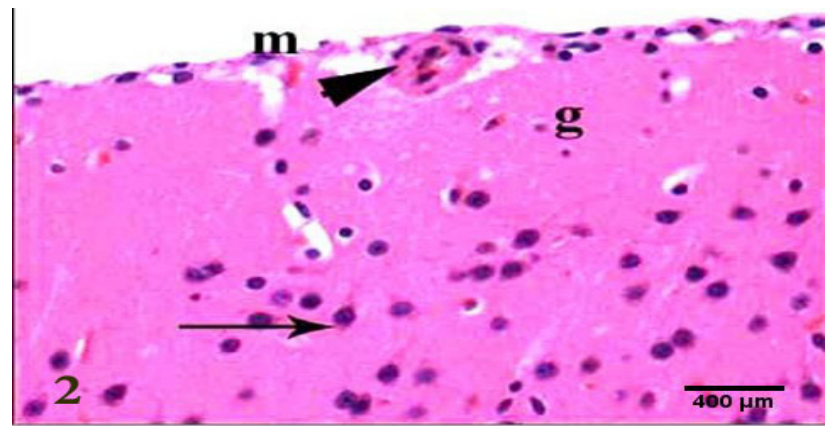

Fig. 2: A magnified part of previous section showing; cortical neurons (arrow) with rounded vesicular nuclei, basophilic cytoplasm and peripheral dendrites. Intercellular neuropils shows different types of neuroglia (g) and nerve fibers. Note: blood vessels (arrow head) are seen under meninges (m). (Group I H\&E x400)

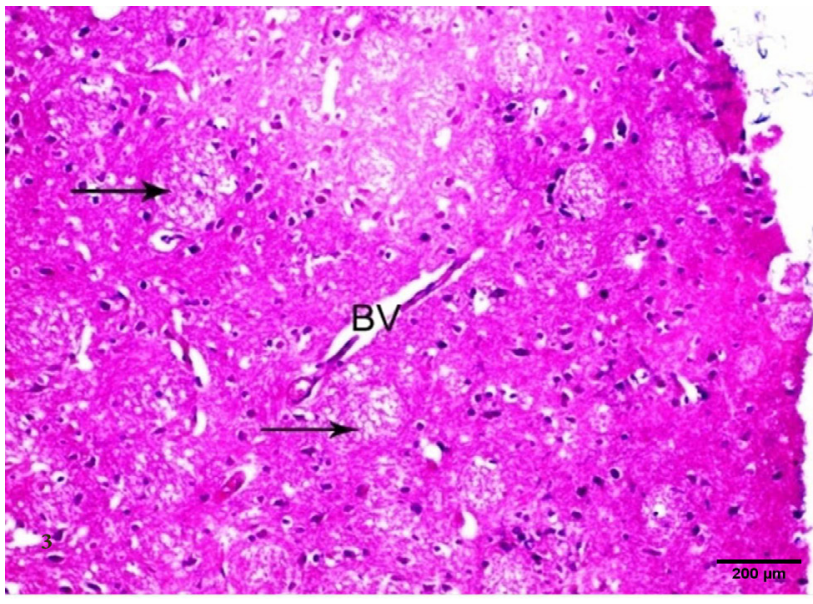

Fig. 3: A photomicrograph of a section from irradiated rat's cerebral cortex showing ., patches of pale areas in between nerve cells ( arrow) ,widened perivascular space (BV) with loss of lamellar pattern (Group II H\&Ex200)

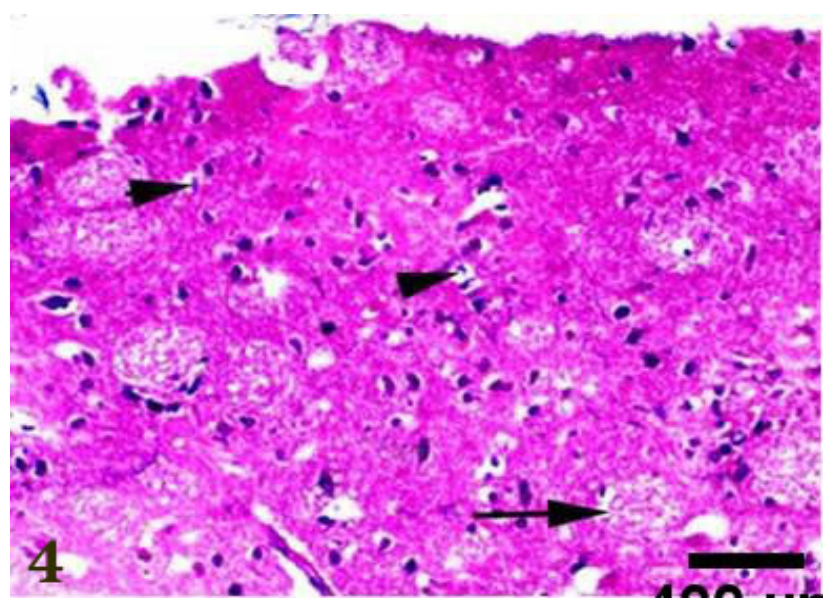

Fig. 4: A magnified image of the previous section showing., areas of cerebral necrosis ( arrow ) with degenerated nerve cells (arrow head) (Group II H\& E X 400)

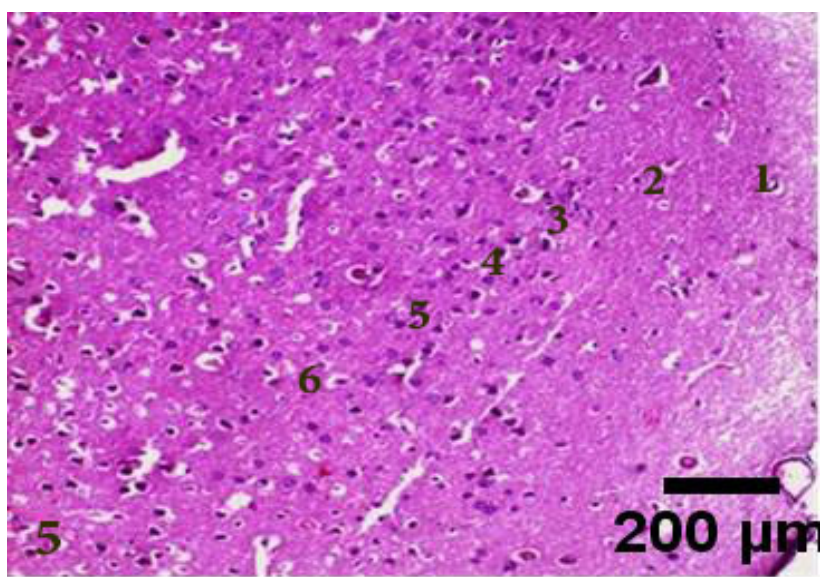

Fig. 5: A photomicrograph of a section of irradiated rat's cerebral cortex pretreated with vitamin E showing., return of the lamellar pattern (Group III H\&E x200) 


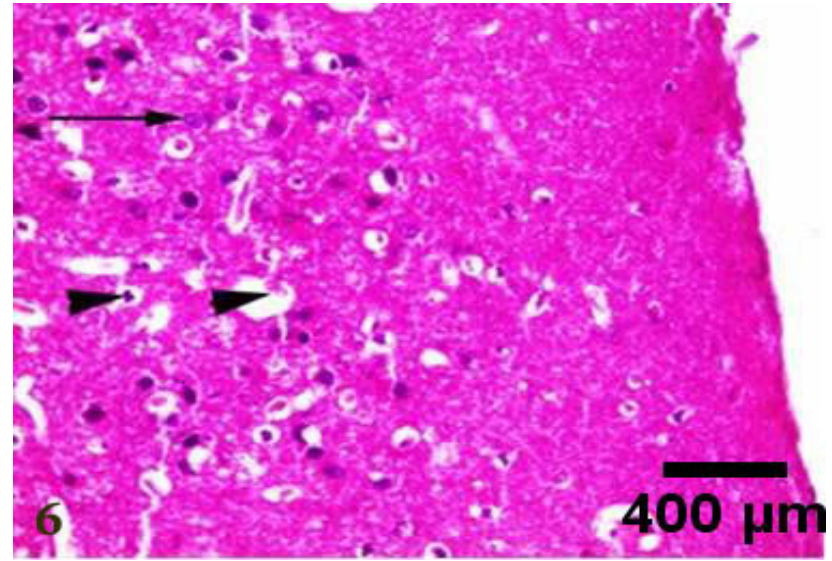

Fig. 6: A magnified image of the previous section showing, most of the nerve cells appear more or less as the control (arrow). Other nerve cells are degenerated.(arrow head) (Group III H\&E x400)

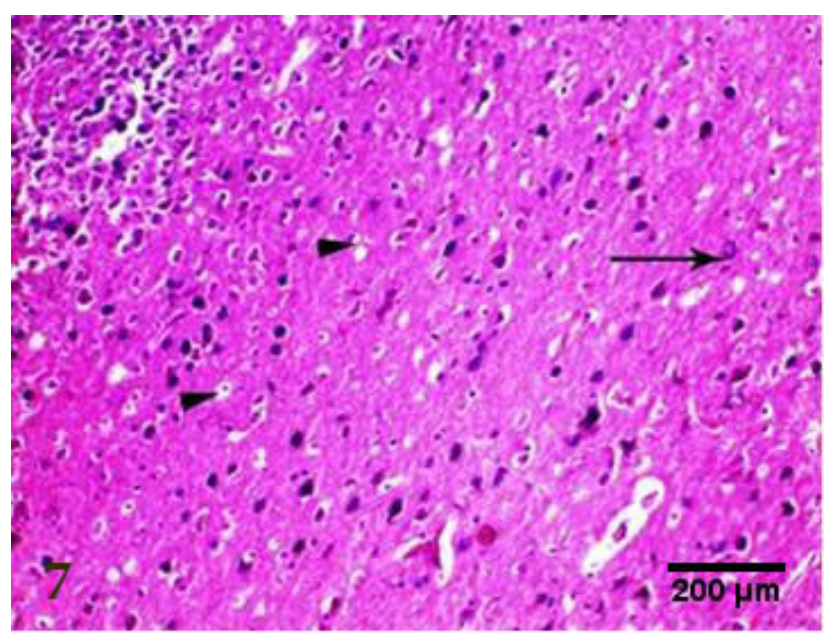

Fig. 7: A photomicrograph of a section from irradiated rat's cerebral cortex pretreated with Nigella showing., Some nerve cells appear more or less as the control (arrow). others appear degenerated (arrow head). (Group IV H\&E X200)

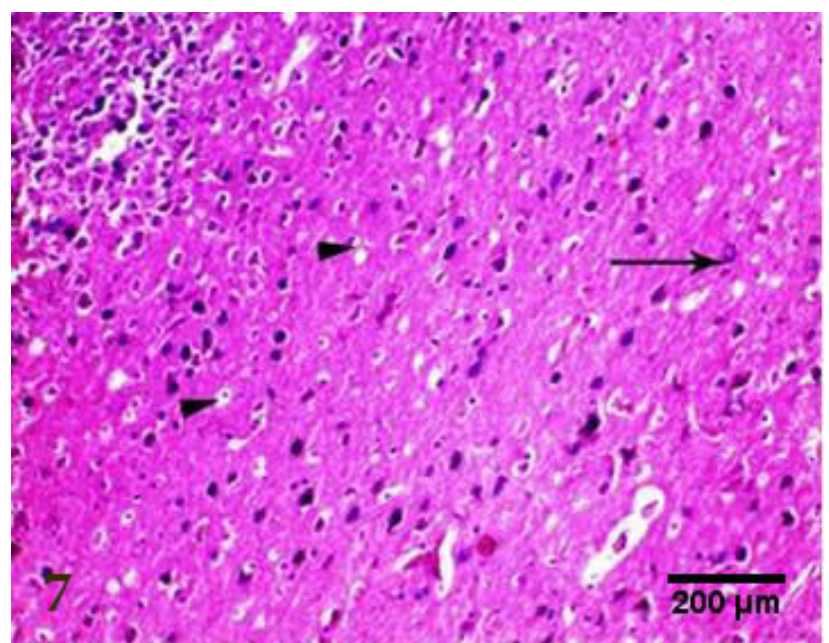

Fig. 8: A magnified image of the previous section showing ., Some nerve cells appear more or less as the control (arrow). Others are degenerated (arrow head ). (Group IV H\&E X400)

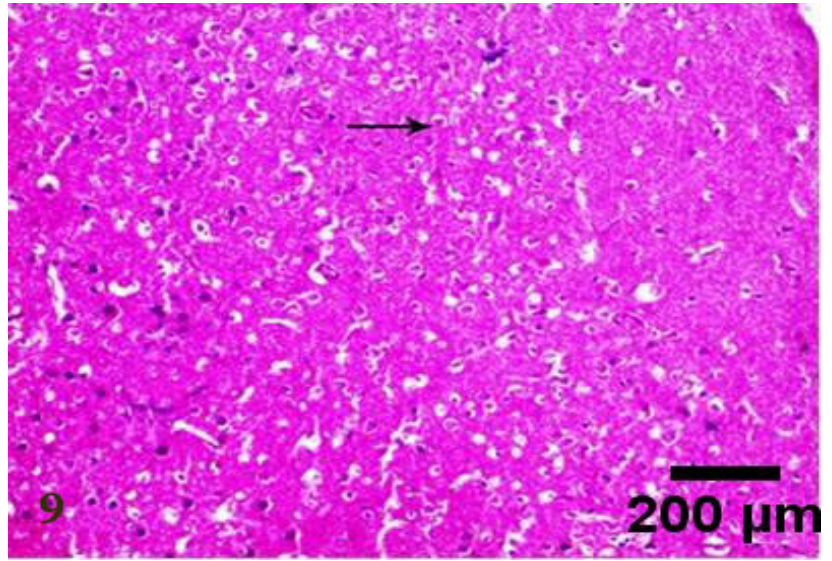

Fig. 9: A photomicrograph of a section from irradiated rat's cerebral cortex pretreated with Melatonin showing some of nerve cells are degenerated leaving empty spaces (arrow), others are similar to control(arrow head). (Group V H\&E X200)

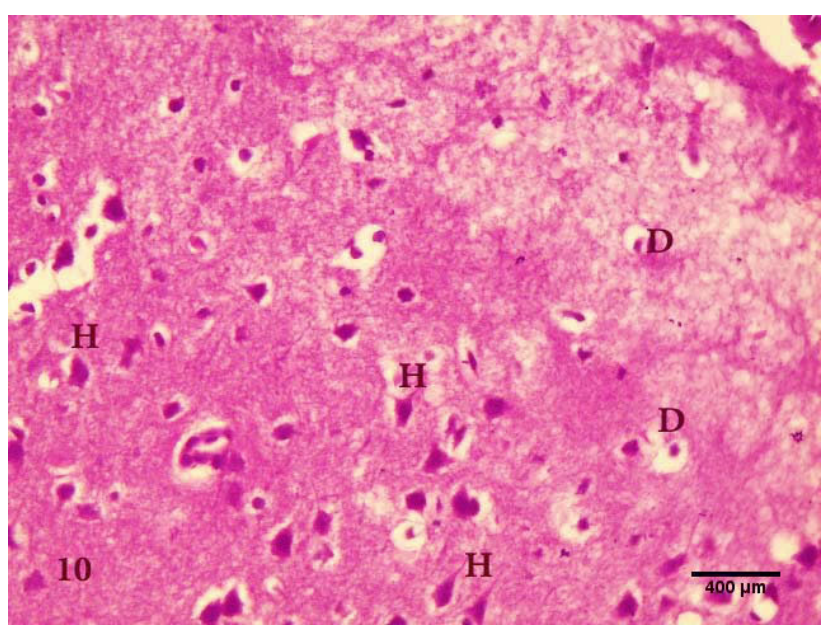

Fig. 10: A photomicrograph from irradiated rat's cerebral cortex pretreated with Melatonin showing some of nerve cells are degenerated leaving empty spaces (D). Others are similar to control (H) (Group V $\mathrm{H} \& \mathrm{E}$ X400)

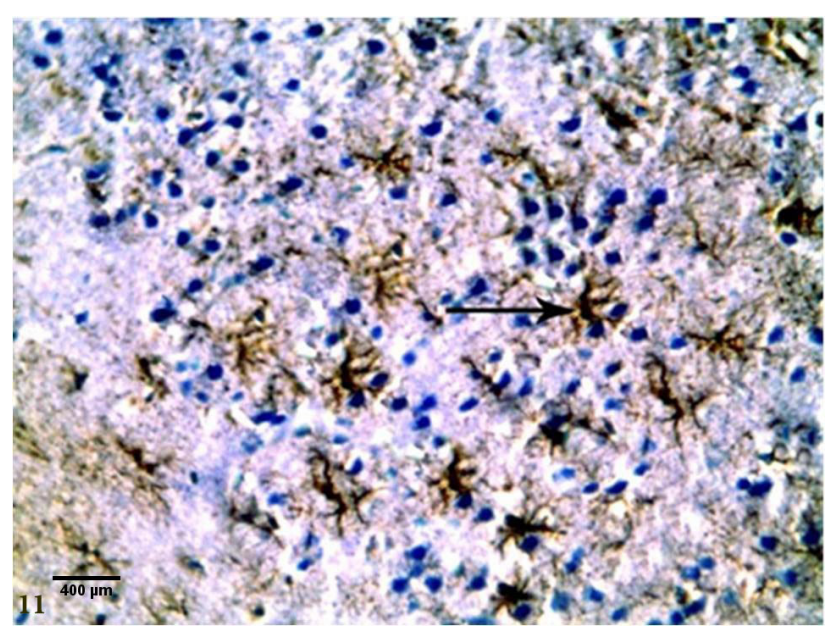

Fig. 11: A photomicrograph of a section from a control rat's cerebral cortex showing astrocytes with few and thin processes (arrow). Note: the brown coloration in the cytoplasm of astrocytes and their processes. ). (Group I GFAP immunostainedx400) 


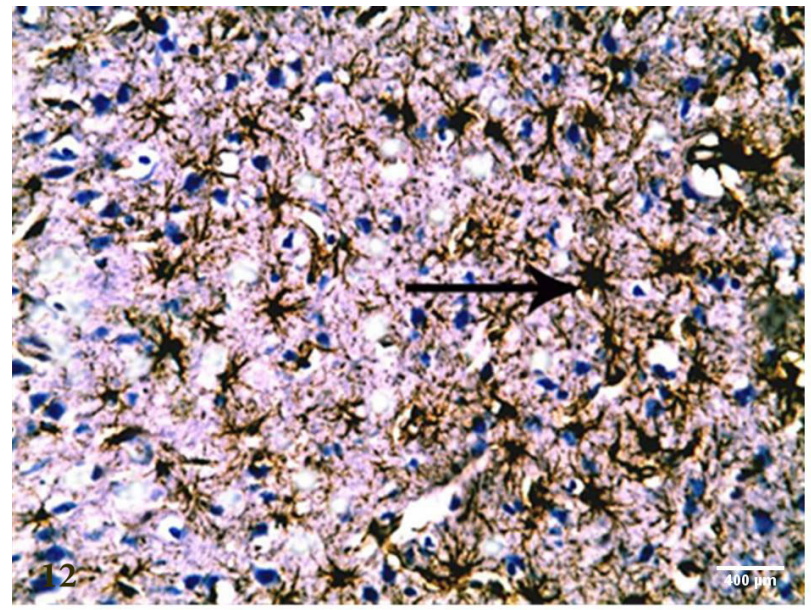

Fig. 12: A photomicrograph of a section from irradiated rat's cerebral cortex showing., proliferation of astrocytes (arrow). (Group II GFAP immunostainedx400)

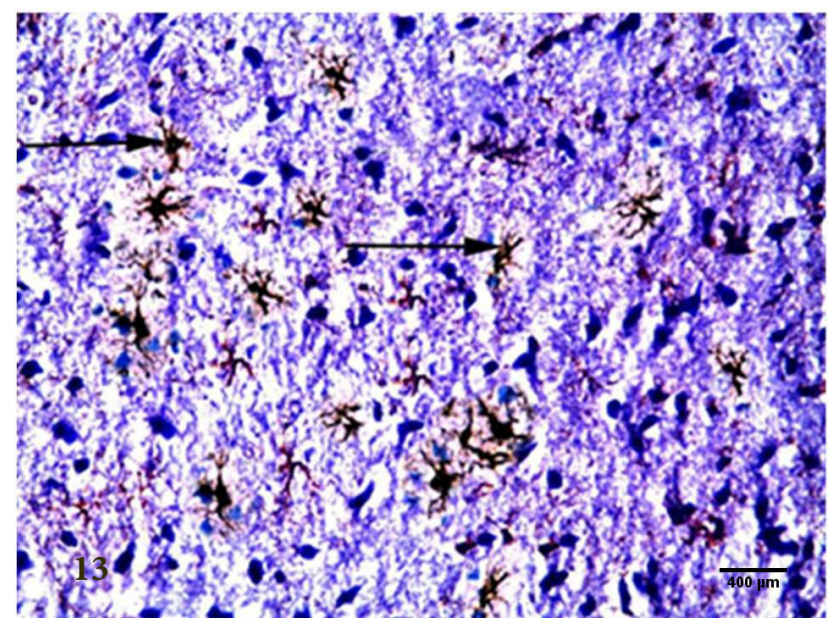

Fig. 13: A photomicrograph of a section from irradiated rat's cerebral cortex pretreated with vitamin E showing., astrocyte number is less than the irradiated one. (Group III GFAP immunostainedx400)

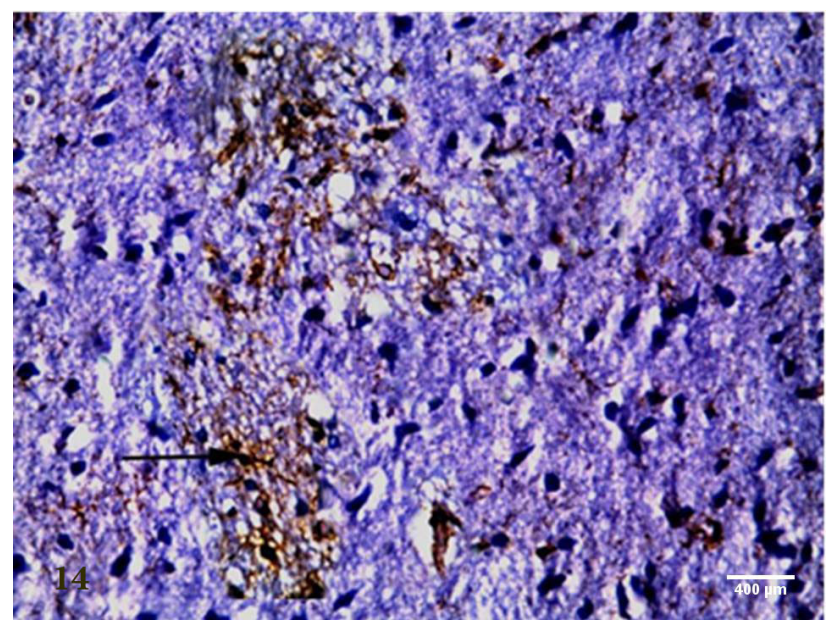

Fig. 14: A photomicrograph of a section from irradiated rat's cerebral cortex pretreated with Nigella showing., astrocyte number is less than irradiated one with localized distribution (arrow) (Group IV GFAP immunostainedx400)

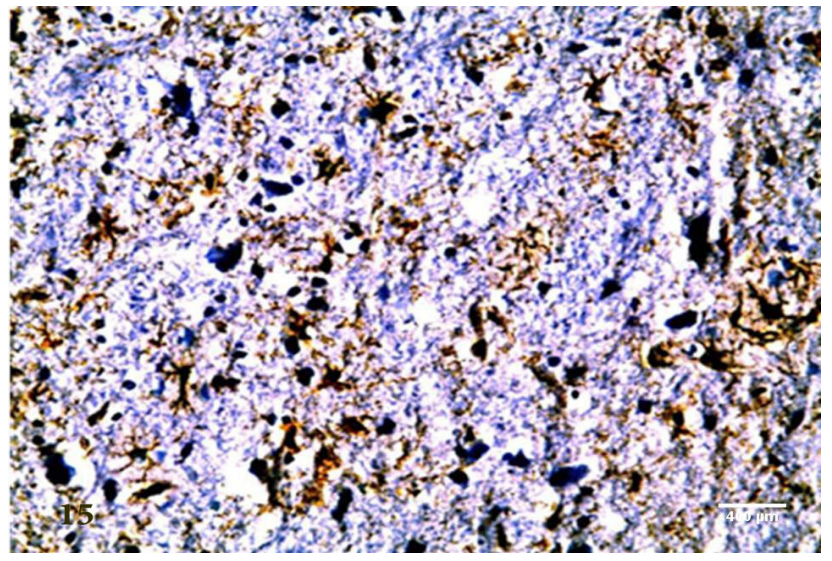

Fig. 15: A photomicrograph of a section from irradiated rat's cerebral cortex pretreated with melatonin showing., astrocyte number is less than irradiated one (arrow) (Group V GFAP immunostainedx400)

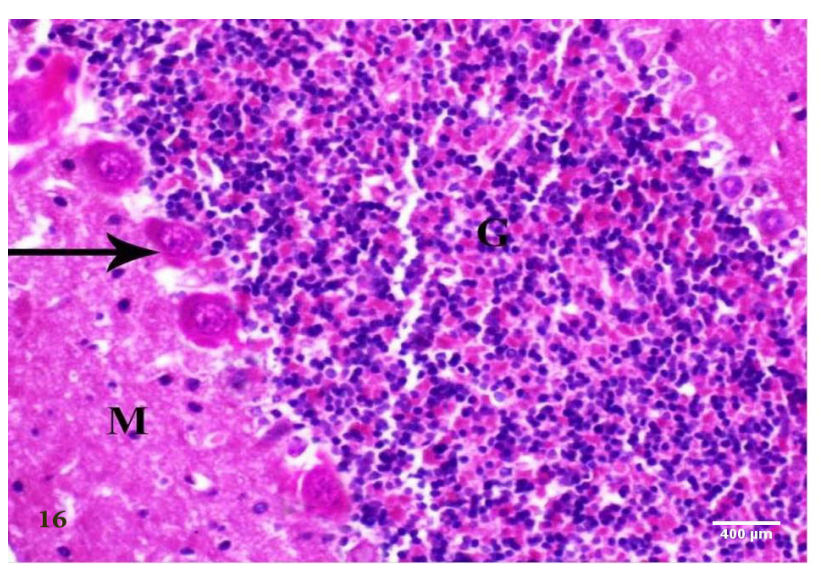

Fig. 16: A photomicrograph of a section from control rat cerebellar cortex showing, molecular layer(M) . Purkinje cell layer with their rounded vesicular nucleus (arrow) and granular cell layer $(\mathrm{G})$ (Group I H\&EX400)

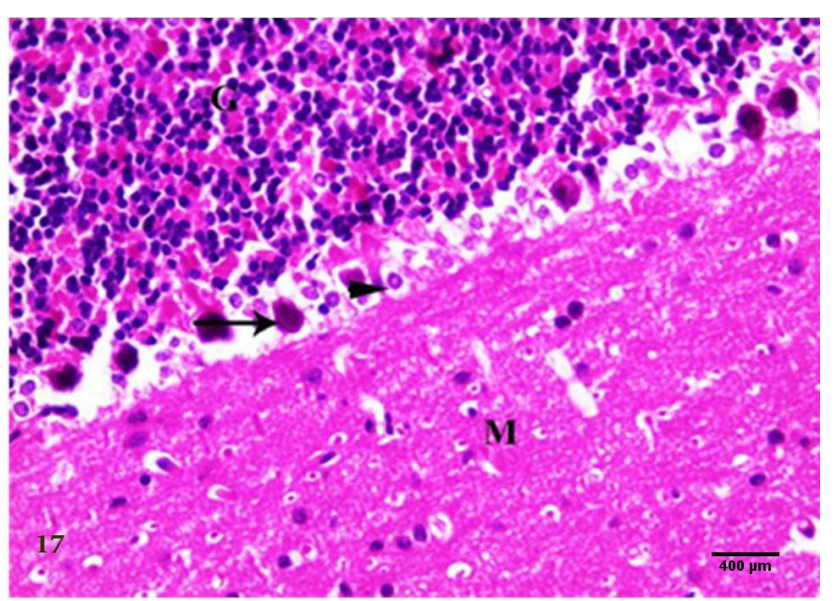

Fig. 17: A photomicrograph of a section from irradiated rat's cerebellar cortex showing., degenerated Purkinje cells with vacuolated cytoplasm (arrow head) other cells are shrunken with deeply stained cytoplasm in granular cell layer(G) and molecular layer are more or less as the control group. There are empty spaces in the molecular layer (arrow). (Group II H\&E X400) 


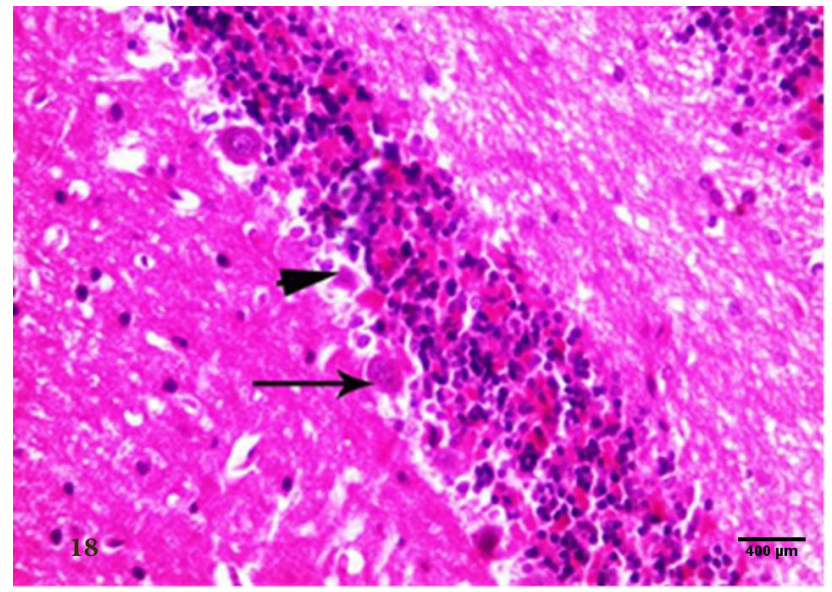

Fig. 18: A photomicrograph of a section from irradiated rat's cerebellar cortex pretreated with Vitamin E showing., some purkinje cells appear more or less as control group (arrow), other cells are shrunken with deeply stained cytoplasm. (arrow head ).Granular layer(G) and molecular layer are more or less as the control group (Group III H\&EX400)

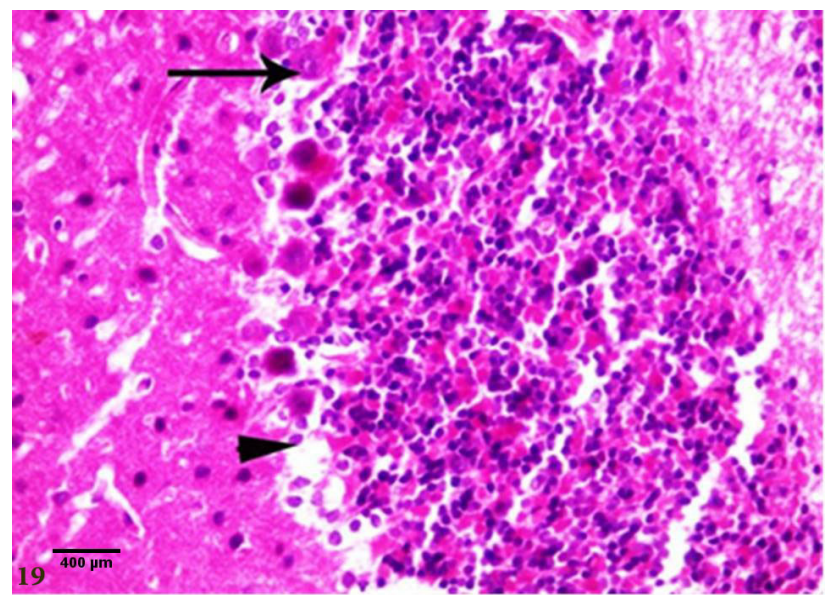

Fig. 19: A photomicrograph of a section from irradiated rat's cerebellar cortex pretreated with Nigella showing., Some Purkinje cells are degenerated other cells are more or less as the control group granular cell layer $(\mathrm{G})$ and molecular layer are more or less as the control group. (Group IV H\&EX400)

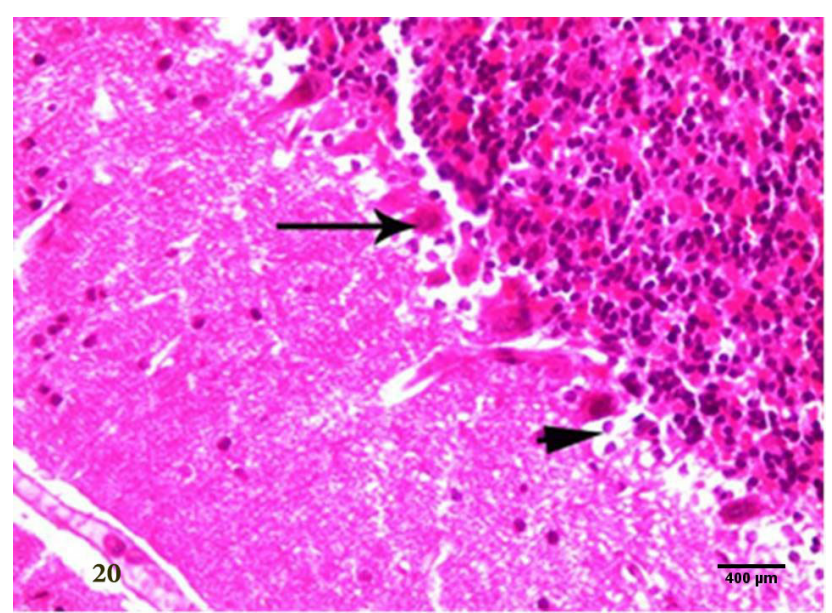

Fig. 20: A photomicrograph of a section from irradiated rat 's cerebellar cortex pretreated with melatonin showing., Some Purkinje cells are degenerated (arrow head) other cells has deeply stained small nuclei. Granular cell layer(G) and molecular layer are more or less as the control group (Group V H\&EX400)

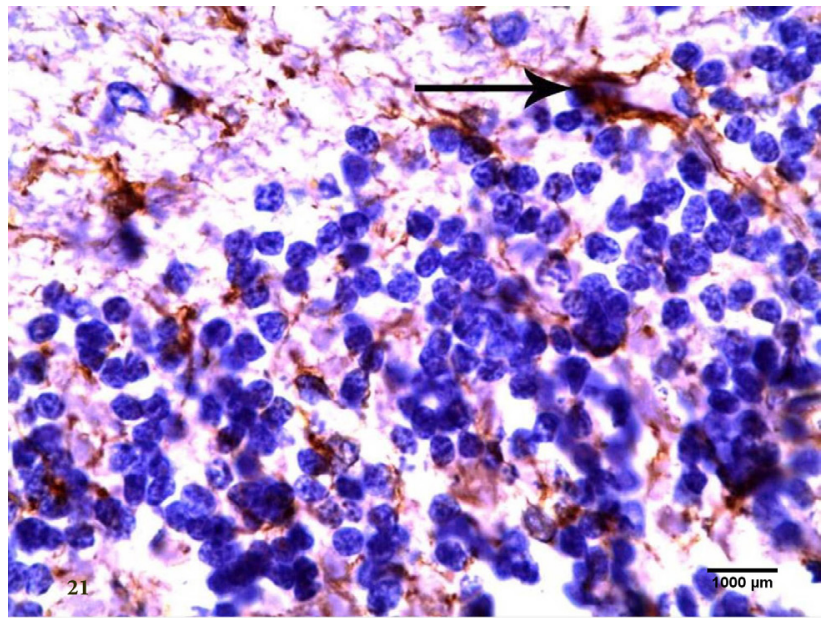

Fig. 21: A photomicrograph of a section from control rat's cerebellar cortex showing, positive immun-reaction for GFAP in the cytoplasm of astrocytes that appear with few, thick processes (arrow) in the granular and pukinje layer . Note: the brown coloration in the cytoplasm of astrocytes and their processes. (Group I GFAP immunostainedx1000)

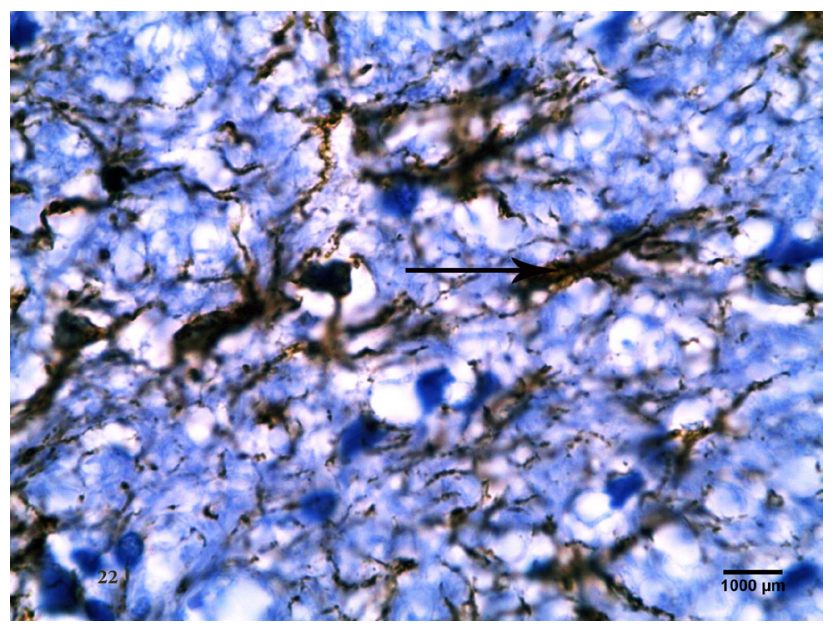

Fig. 22: A photomicrograph of a section from irradiated rat's cerebellar cortex, showing the number of astrocytes as well as intensity of their reaction for GFAP staining increased compared to the control group (Group II GFAPimmunostainedx1000)

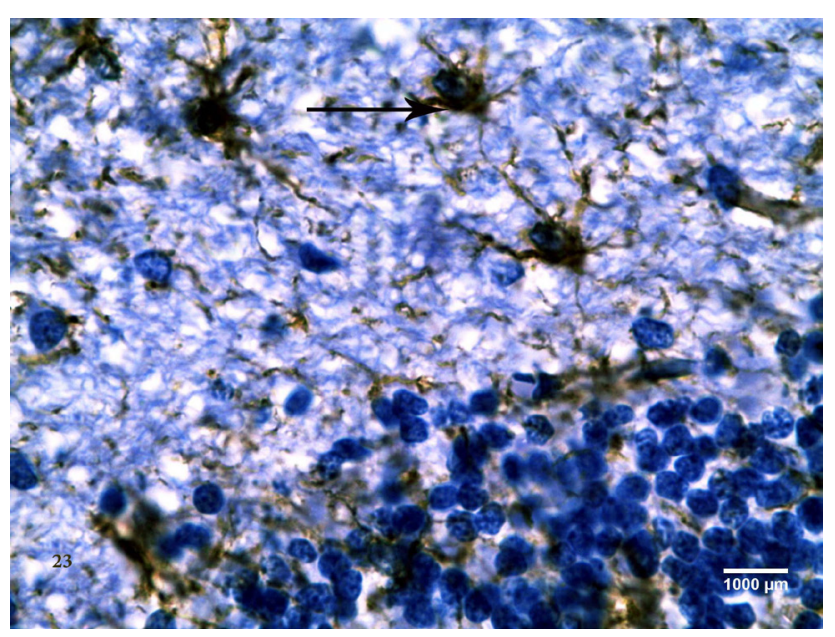

Fig. 23: A photomicrograph of a section from irradiated rat's cerebellar cortex pretreated with vitamin E showing, the number of the astrocyte as well as their intensity of the reaction are less than irradiated one (Group III GFAP immunostainedx1000) 


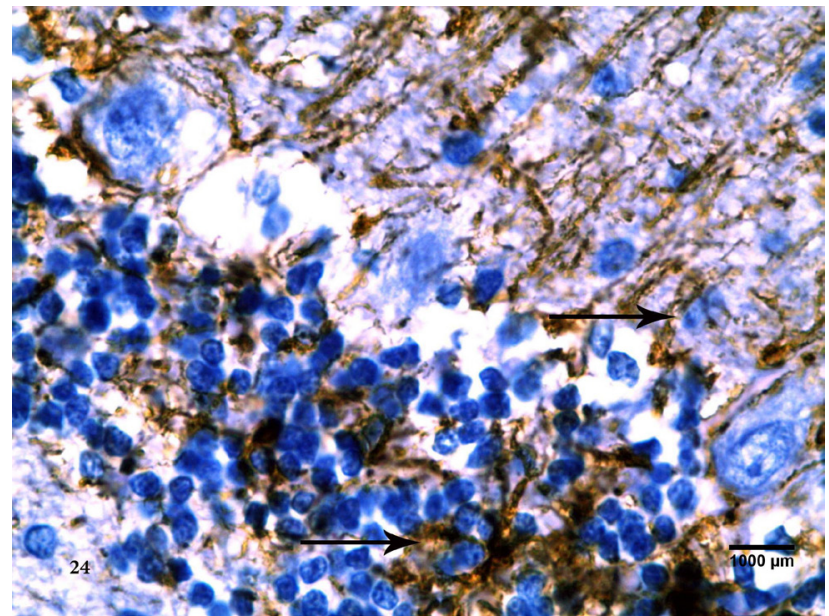

Fig. 24: A photomicrograph of a section from irradiated rat's cerebellar cortex pretreated with Nigella showing, the astrocyte number and intensity of staining are less than irradiated group (Group IV GFAP immunostainedx1000)

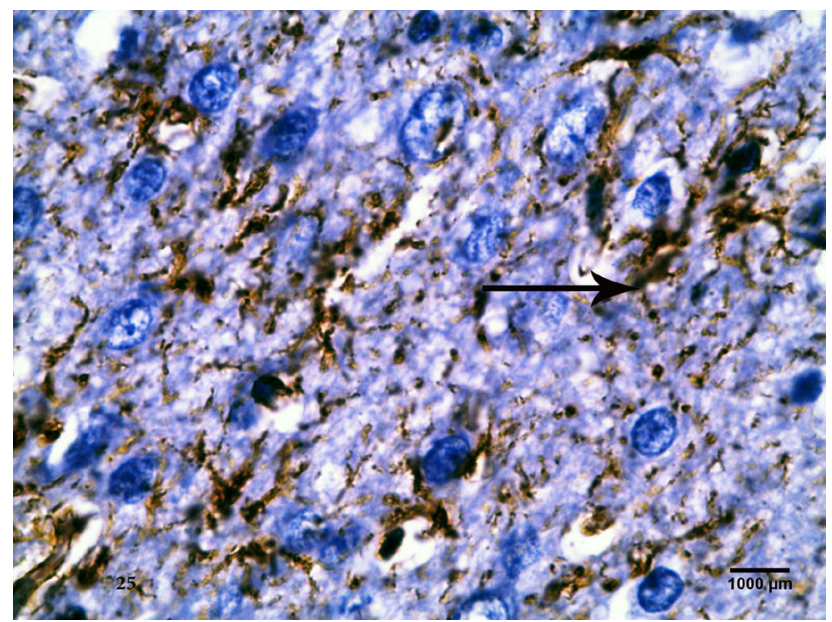

Fig. 25: A photomicrograph of a section from irradiated rat's cerebellar cortex pretreated with Melatonin showing, the astrocyte number is less than the irradiated one (Group V GFAP immunostainedx 1000)

Table 1: Mean of GFAP positive cells in the brain

\begin{tabular}{ccc}
\hline Groups & mean \pm SD & P value \\
\hline GI & $22.8 \pm 5.44$ & \\
GII & $32.2 \pm 6.68$ & $0.001^{*}$ \\
GIII & $24.4 \pm 4.33$ & \\
GIV & $20 \pm 8.33$ & \\
GV & $19.8 \pm 7.75$ & \\
\hline
\end{tabular}

Table 2: Mean of GFAP positive cells in the cerebellum

\begin{tabular}{ccc}
\hline Groups & mean $\pm \mathrm{SD}$ & Pvalue \\
\hline GI & $9.8 \pm 0.83$ & \\
GII & $19.4 \pm 1.1$ & $0.000^{*}$ \\
GIII & $9.2 \pm 0.83$ & \\
GIV & $9.8 \pm 1.3$ & \\
GV & $9.4 \pm 0.89$ & \\
\hline
\end{tabular}

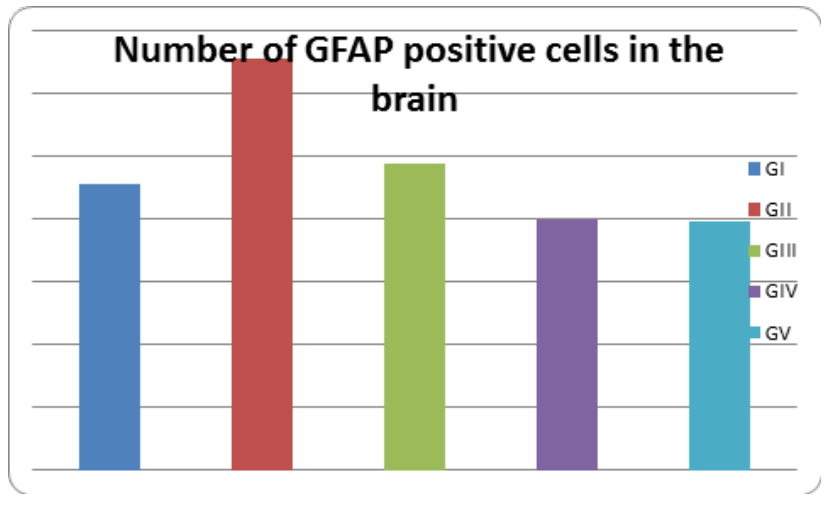

Histogram 1: Showing the difference between GFAP positive cells in the brain

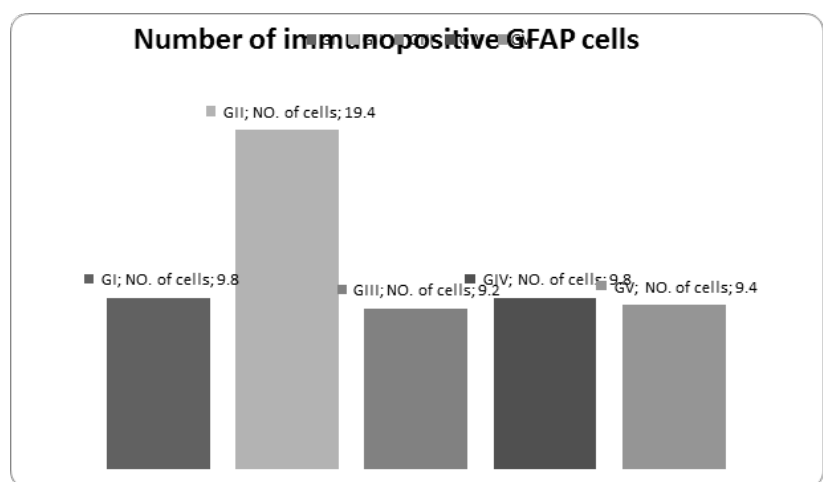

Histogram 2: Showing the difference in GFAP positive cells in the cerebellar cortex between the different groups.

\section{DISCUSSION}

Cranial radiation is an essential therapeutic tool in the treatment of primary and secondary brain tumors. It has adverse effects including cognitive dysfunction which can affect the quality of life $\mathrm{e}^{[1,2]}$.

Radiation affect normal tissues a well as the tumor mass. The effect on normal tissue can range from mild discomfort to life threatening effects. The rates of these responses depend on the amount and distribution of the dose of radiation received by tissues ${ }^{[3,4]}$.

Although x-ray is widely used for both imaging and therapeutic purposes, their possible early and acute morphological changes on the cerebral and cerebellum cortices are few in literature.

In the present study, irradiation resulted in necrosis and degenerative changes in the cerebral cortex. These results are in accordance with Erol et al., 2004 who reported that 7.2 Gy whole body induced brain necrosis and neuronal degeneration with an increase in brain malonaldehyde level which is an oxidative stress marker ${ }^{[22]}$. Other studies reported that exposure of male rabbits to radiation showed increase in the oxidative stress markers resulting in brain necrosis and congestion ${ }^{[23]}$. 
Brain tissues are highly sensitive to abnormal levels of reactive oxygen species and their defensive mechanisms are limited. Moreover, the free radical are involved in the development of the inflammatory response, which is an important element of the pathogenesis of neurodegenerative diseases such as Alzheimer's disease ${ }^{[24]}$ or Parkinson's disease $^{[25]}$.

A significant increase in the number of GFAP positive astrocytes was observed in the present study in the XRI group compared to the control. This is in accordance with Chan and his colleagues (2009) who reported, the hypertrophy and hyperplasia of GFAP positive astrocytes at the site of irradiation in the ipsilateral brain relative to the contralateral side ${ }^{[26]}$.

Reactive gliosis is a reaction to brain injury to restrict inflammation and neuronal death. Astrocytes react to injury by hypertrophy and up-regulation GFAP. It is reported that some astrocytes acquire stem cell properties in adult mouse cerebral cortex after injury and hence may provide a promising cell type to initiate repair after brain injury $^{[27,28,29]}$.

The cross-link between astrocyte and neuron occurs through the release of several neurotrophic factors that maintain CNS homeostasis ${ }^{[30,31]}$. Activated astrocytes secrete different neurotrophic factors to improve the neuronal survival. On the other hand, it was found that rapid and severe activation led to an inflammatory response and neuronal death ${ }^{[32,33]}$.

Some studies suggest that intrinsic recovery and repair responses induced by specific cytokines released by astrocytes may initiate secondary reactive processes, resulting in the progressive development of a persistent oxidative stress on the CNS months after irradiation and that this oxidative stress may induce the development of radiation injury in the more sensitive white matter of the brain ${ }^{[34]}$. Some studies demonstrated that vascular/ inflammatory morphologic changes predominate the earliest stages of the post-radiation response and are followed by morphologic cellular and interstitial changes in the CNS white matter ${ }^{[35]}$. Some explanations reported by other authors, impaired perfusion due to cerebral vessel occlusion resulting from luminal constriction because of fibrinoid necrosis, endothelial proliferation, and periadventitial fibroblastic proliferation with coexistent thrombus plays an important role in the development of late radionecrosis ${ }^{[36]}$. The development and extent of all these pathologies depend on radiation dose, duration of administration, and frequency ${ }^{[37]}$.

In the present study, Pre-irradiation use of vitamin $\mathrm{E}$ resulted in return of the lamellar pattern in the cerebral cortex with some nerve cells appeared degenerated. Immunohistochemical and morphometric study revealed a significant decrease in number of astrocytes compared to the previous group. Some studies revealed that vitamin E therapy reduced radiation injury via its antioxidant effects by combating free radicals, whether given before or immediately after irradiation ${ }^{[38]}$. Additionally, vitamin E supports immunity and protects bone marrow cells from the harmful effects of gamma radiation by not only scavenging free radicals but also stimulating the repairing factors of $\mathrm{DNA}^{[39]}$. Some authors found that vitamin E reduced only necrosis but did not prevent vasodilatation ${ }^{[40]}$.

Previous studies on rats have shown that vitamin E and other antioxidant vitamins, by decreasing oxidative stress, could have protective effect against radiation-induced injuries such as oral mucositis, myelosuppression ${ }^{[41]}$, intestinal injuries ${ }^{[42]}$, lipid and DNA damage to the liver ${ }^{[43]}$, and cataract ${ }^{[44]}$. Protection against radiation-induced damage in small bowel crypts of rats ${ }^{[45]}$, modification of micronucleus induction by $\mathrm{g}$ rays in mice ${ }^{[46]}$, and invitro reduction in the number of micronuclei in human lymphocytes before and after gamma-ray irradiation have also been reported by others ${ }^{[15]}$. The same results were found in salivary gland ${ }^{[47]}$. On the other hand, some authors found no changes resulted in pre-irradiation treatment with vitamin $\mathrm{E}^{[48]}$.

In a similar study, Siu et al. investigated lipid antilipid peroxidation effects of melatonin and vitamin $\mathrm{E}$ on retinal homogenates in rats and found that melatonin's prevention of lipid peroxidation was 7.2-fold greater than that of vitamin $\mathrm{E}^{[49]}$.

Brain tissue is highly sensitive to free-radical damage because of its low level of endogenous antioxidants, notably vitamin E and superoxide dismutase. Vitamin E protects the integrity of acetyl choline receptors in normal neurons. it prevents toxicity and apoptosis induced by ROS producing amyloid _ peptides that increase in the brain with age and in dementia ${ }^{[50]}$.

In the current study, examination of the rat's cerebral cortex treated with Nigella revealed nerve cells appeared more or less as the control group. There was a highly significant decrease in the number of astrocytes in nigella treated group compared to the XRI one. Similar results were reported by others in the liver tissue. It was found that nigella sativa oil reduced oxidative stress and has antioxidant effects when administered 1 hour before irradiation ${ }^{[21,51]}$. Some authors found that extract of Nigella sativa seeds, could be used in combination with radiation to protect against oxidative stress in normal tissues and improve the quality of life of cancer patients by mitigating unwanted side effects of radiation in normal tissues ${ }^{[52]}$.

In the present study, melatonin pretreated group showed partial improvement with a significant decrease in the number of GFAP positive astrocytes. Erol and his colleagues (2004) reported that melatonin may be useful in preventing the pathological changes of secondary brain damage as a result of free oxygen radicals generated by irradiation $^{[22]}$.

Also, melatonin reduces oxidative stress markers and augments anti-oxidant capacity in the rat lens ${ }^{[53]}$ and testi $^{[19]}$. It also provide a significant decrease in the DNA 
strand breakage and lipid peroxidation hence protect brain cells from oxidative damage induced by radiation ${ }^{[54]}$.

These results are in accordance with the studies of pretreatment with melatonin prevented radiation induced damage on peripheral blood cells ${ }^{[55]}$. Irradiation with 6 and 8 Gy associated with increased malonaldehyde, nitric oxide levels and were reduced with melatonin ${ }^{[56]}$. Therefore, melatonin by its antioxidant properties and free radical scavenging ameliorates irradiation induced cell damage ${ }^{[57]}$. Babaee reported that melatonin could protect neurons and glial cells following traumatic brain injury in rat. Its administration decreasing GFAP positive astrocyte number (astrogliosis), as well as the number of apoptotic neurons in brain cortex of traumatic brain injury ${ }^{[58]}$.

Experimental and clinical data confirmed that melatonin has anti-inflammatory effect and exerts important role in the reduction of adhesion molecules and pro-inflammatory cytokines. In addition to its direct free radicals scavenger and antioxidant enzymes stimulating effect ${ }^{[59]}$.

In the current study, with examination of irradiated rat cerebellar cortex, mild dissociation of Purkinje cell layer and molecular layer was observed. Purkinje cells showed degenerative changes. Win et al., 2000 reported that, although Purkinje cells were resistant to X-ray induced mortality, they exhibited disturbed alignment with abnormal dendritic arborization ${ }^{[60]}$. Many authors suggested that susceptibility of the cerebellum to irradiation should be taken into consideration for future protective strategies ${ }^{[61]}$. This is in accordance with the study of Li Cui and his colleagues ${ }^{[62]}$ which reported that total body irradiation significantly increased vacuolization of the molecular layer. At high magnification, deformed fiberlike structures were found along with the empty matrix space. Necrotic Purkinje cells were observed. Substantial damage to the cerebellum can be detectable as early as 13.5 days in adult animals following sublethal total body irradiation. Oxidative stress, inflammatory response and calcium neurotoxicity-associated mechanisms are involved in radiation-induced neuronal damage. Some authors explained the oxidative stress that irradiation induces radiolysis of water. It generates reactive radicals, which initiate oxidative damage of intracellular target molecules including RNA, DNA and membrane lipid ${ }^{[63]}$. Similar findings were reported in irradiation-induced chronic neuronal damage: Oxidative stress, inflammatory response and calcium neurotoxicity-associated mechanisms are involved in radiation-induced neuronal damage ${ }^{[64]}$.

In our results, there was proliferation of the astrocytes with increase their intensity for staining in examination of irradiated rat's cerebellar cortex. These results in accordance with some authors who explained this due to astrocytes preserve neuronal survival through inactivation of $\operatorname{ROS}^{[65]}$. Glial cells exhibit one of the earliest and most obvious cellular responses, reactive gliosis, following a variety of insults to the $\mathrm{CNS}^{[66]}$.
Examination of irradiated rats pretreated with vitamin E showed partial improvement of Purkinje cells changes. It is known that the brain tissue is highly sensitive to freeradical damage because of its low level of endogenous antioxidants, notably vitamin $\mathrm{E}$ and superoxide dismutase. Vitamin E protects the integrity of acetyl choline receptors in normal neurons and prevents toxicity and apoptosis induced by ROS-producing amyloid $\beta$ peptides that increase in the brain ${ }^{[50]}$. The role of vitamin $\mathrm{E}$ is to scavenge free radicals thereby preventing radiation-induced damage to the cell membrane[ $\left[{ }^{67]}\right.$. The action of free radicals leads to oxidative stress and lipid peroxidation, which may result in cell death ${ }^{[68]}$. Further investigation is required to assess other radiation doses and evaluation times and mainly for application in humans ${ }^{[20]}$. Farombi and Onyemamentioned that, dietary antioxidants as vitamin $\mathrm{E}$ had protective potential against oxidative stress induced by some toxins ${ }^{[69]}$. Some studies reported that vitamin $E$ reduced only necrosis in rat exposed to gamma irradiation ${ }^{[40]}$, while others reported that, protective effects of vitamin $\mathrm{E}$ were not observed in their study ${ }^{[70]}$.

In the present study, The rat cerebellar cortex, treated with Nigella, was similar to control group. Few showed some degenerated Purkinje cells. These results are in accordance with previous study of Ahamed and Siddiqui who found that Nigella sativa has reduced the damage done to the cerebral cortex and this agrees to the fact that natural compounds are rich in antioxidants, can reduce oxidative stress and alleviate the effect of oxidative agents $^{[71]}$. Kanter in 2008 obtained similar results when he evaluated the effects of N. sativa on induced neuronal injury by chronic toluene exposure in the frontal cortex and brain stem in rats. He reported no histopathological lesions after treatment with nigella sativa for 12 weeks ${ }^{[72]}$. Nigella sativa also provided protection to hippocampal cells exposed to lead and the frontal cortex ${ }^{[73]}$. The findings of this study also indicate a dose dependant relationship.

The same results obtained by Jagetia and Ravikiran ${ }^{[51]}$. They explained this radioprotective effect may be due to free radical scavenging and increased antioxidant status. They said that administration of NSE protected mice against the radiation-induced sickness and mortality. The principle mechanism of radioprotection seems to be scavenging of various radiation-induced free radicals and increase in the activity of antioxidant enzymes. The molecular mechanisms that may have played important role in radioprotection by NSE include inhibition of radiation-induced transactivation of $\mathrm{NF}-\kappa \mathrm{B}$, suppression of radiation-induced elevation in COX-II expression. They suggested that its radioprotective action may be mediated by the presence of various phytochemicals including thymoquinone, nigellidine, and sesquiterpenelongifolene. Other authors proved the radioprotective effect of Nigella on peripheral blood ${ }^{[74]}$. 
In our study, an examination of cerebellar cortex of rats treated with melatonin demonstrates that most Purkinje cells are similar to control group. Granular cell layer and molecular layer are more or less as the control group. This is in accordance with Sisodia and his colleagues supported the idea that melatonin may be used as an antiirradiation drug due to its potent free radical scavenging and antioxidative efficacy ${ }^{[75]}$.

The same results obtained by Cakman and his colleagues on salivary gland ${ }^{[17]}$ bone ${ }^{[71]}$ and radisensitive organs as skin, GIT and bone marrow ${ }^{[76]}$. Some authors explain mechanism of melatonin radioprotective effect by many theories. Melatonin is antioxidant and free radicle scavengers ${ }^{[78 \& 79]}$. So it has neuroprotective mechanism ${ }^{[80]}$. Melatonin is able to reduce the incidence of necrosis and subsequent inflammatory responses after total body irradiation.

Melatonin administration to rats has shown amelioration of neuronal necrosis and degeneration, leading to reduction of edema and histopathological changes in the brain ${ }^{[40]}$. Melatonin has shown ability to change genes involved in apoptosis. The most common regulatory genes involved in apoptosis following exposure to radiation are Bcl2 and $\mathrm{Bax}^{[81]}$. After exposure to IR, down regulation of Bcl-2 and upregulation of Bax stimulate apoptosis via stimulation of caspase- 3 and release of cytochrome $\mathrm{C}$ from the mitochondria. Mohseni and his colleagues. evaluated the anti-apoptosis role of melatonin on rat's peripheral blood lymphocytes. Their results showed that melatonin reduces apoptosis via reduction of bax/bcl-2 ratio. This was more obvious for higher doses of melatonin ${ }^{[81]}$. Similar results were obtained in an in vitro study by Jang et al. ${ }^{[82]}$. Melatonin is a potent stimulator of DNA repair responses such as BER pathway genes. These properties of melatonin could alleviate acute reactions during radiotherapy ${ }^{[76]}$. Melatonin counteract any potential oxidative DNA damage in lung tissue after partial body irradiation. Melatonin could modulate the indirect destructive effect of radiation and reduce DNA damage in non-targeted cells ${ }^{[83]}$. In our study. Cerebellum pretreated with melatonin showed decrease in astrocytes than irradiated ones. This is explained by Baydas and his colleagues (2003). Their results suggest that elevated oxidative stress causes increased glial reactivity and administration of melatonin represents an achievable adjunct therapy for preventing gliosis ${ }^{[84]}$.

\section{CONCLUSION}

Vitamin E, Nigella sativa and Melatonin are strong antioxidant and neuroprotective agents against brain and cerebellar damage induced by radiation.

\section{ACKNOWLEDGMENT}

A lot of thanks to the members of Department of Radiology and Oncology, Sohag University Hospitals, Egypt for carrying out radiation of rats.

\section{CONFLICT OF INTEREST}

There are no conflicts of interest.

\section{REFERENCES}

1. Khuntia D, Brown P, Li J,Mehta M. (2006): Whole brain radiatiotherapy in the management of brain metastasis.J Clin Oncol;24:1295-1304.

2. Scoccianti S, Detti B, Cipressi S, Innalfi A, Franzese C, et al. (2012): Changes in neurocognitive functioning and quality of life in adult patients with brain tumours treated with radiotherapy. J Neuro Oncol Feb 18 (E pub a head of print).

3. Steel G. Basic Clinical Radiobiology. $3^{\text {rd }}$ edition. Edward Arnold; 2002.

4. Shirazi A, Ghobadi G, Ghazi-Khansari M. A radiobiological review on melatonin: a novel radioprotector. Journal of Radiation Research. 2007;48(4):263-272.

5. Lee HJ, Kim SR, Kim JC, Kang CM, Lee YS, Jo SK, Kim TH, Jang JS, Nah SY, Kim SH, In vivo radioprotective effect of Panax ginseng C.A. Meyer and identification of active ginsenosides, Phytother Res, 2006, 20(5):392-395.

6. Farombi EO, Ugwuezunmba MC, Ezenwadu TT, Oyeyemi MO, Ekor M, Tetracycline-induced reproductive toxicity in male rats: effects of vitamin $\mathrm{C}$ and $\mathrm{N}$-acetylcysteine, Exp Toxicol Pathol, 2008, 60(1):77-85.

7. Al Ghamdi SS. Nigella sativa seeds protect from viral hepatitis B virus infection. Curr Top Pharmacol 2008; 12:101-104.

8. Ochiaia T, Ohnoa S, Soedaa S, Tanakab H, Shoyamab Y, Shimenoa H. 2004. Crocin prevents the death of rat pheochromyctoma (PC12) cells by its antioxidant effects stronger than those of $\alpha$-tocopherol. Neurosci Lett, 362: 61-64.

9. Ali BH, Blunden G. (2003). Pharmacological and toxicological properties of Nigella sativa. Phytother. Res, 17: 299-305.

10. Kanter M, Coskun O, Kalayci M, Buyukbas S, Cagavi F. (2006). Neuroprotective effects of Nigella sativa on experimental spinal cord injury in rats. Hum Exp Toxicol, 25: 127- 133.

11. Gilhotra N, Dhingra D. (2011). Thymoquinone produced antianxiety-like effects in mice through modulation of GABA and NO levels. Pharmacol Rep, 63: 660-669.

12. Salem, ML. (2005). Immunomodulatory and therapeutic properties of the Nigella sativa L. seed. Int. Immunopharmacol, 5: 1749-1770. 
13. Ahlatci A, Kuzhan A, Taysi S, Demirtas OC, Alkis HE, Tarakcioglu M, Demirci A, Caglayan D, Saricicek E, Cinar K. Radiation-modifying abilities of Nigella sativa and thymoquinone on radiation-induced nitrosative stress in the brain tissue. Phytomedicine. 2014 Apr 15;21(5):740-4.

14. Ramos FMMR, Pontual MLA, Almeida SM, Boscolo FN, Tabchoury CP, Novaes PD.(2006). Evaluation of radioprotective effect of vitamin $\mathrm{E}$ in salivary dysfunction in irradiated rats. Arch Oral Biol;51:96-101.

15. Konopacka M, Widel M, Rzeszowska-Wolny J. 2001:Antioxidants vitamins C, E and beta carotene reduce DNA damage before as well as after gammaray irradiation of human lymphocytes in vitro. Mutat Res;491:1-7. 1 A

16. Ehsan Mihandoost, Alireza Shirazi, , Seied Rabie Mahdavi, and Akbar Aliasgharzadeh. (2014): Can Melatonin Help Us in Radiation Oncology Treatments? Biomed Res Int.

17. Cakmak Karaer I, Simsek G, Yildiz A, Vardi N, Polat A, Tanbek K, Gurocak S, Parlakpinar H.(2016): Melatonin's protective effect on the salivary gland against ionized radiation damage in rats. J Oral Pathol Med. Jul;45(6):444-9.

18. El-Missiry MA, Fayed TA, El-Sawy MR, El-Sayed AA.(2007): Ameliorative effect of melatonin against gamma-irradiation-induced oxidative stress and tissue injury. Ecotoxicol EnvironSaf. Feb;66(2):278-86. Epub 2006 Jun 21.

19. Mahmoud R. Hussein, Eman E. Abu-Dief, Amal T. Abou El-Ghait, Mohamed A. Adly and Mohamad H. Abdelraheem(2006): Morphological evaluation of the radioprotective effects of melatonin against X-rayinduced early and acute testis damage in Albino rats: an animal model Int. J. Exp. Path. 87, 237-250

20. Carolina Cintra Gomes, Flávia Maria de Moraes, Ramos-Perez Danyel Elias da Cruz Perez and Solange Maria De Almeida (2013): Radioprotective Effect of Vitamin E in Parotid Glands: A Morphometric Analysis in Rats, Brazilian dental journal 24(3):183-7

21. Cikman O, Ozkan A, Aras A, Soylemez O, Alkis H, Tayasis Karayraz M (2014): Radioprotective Effects of Nigella Sativa Oil Against Oxidative Stress in Liver Tissue of Rats Exposed to Total Head Irradiation J Invest Surg. Oct;27(5):262-6.

22. Erol FS, Topsakal C, Ozveren MF, et al. Protective effects of melatonin and vitamin $\mathrm{E}$ in brain damage due to gamma radiation: an experimental study. Neurosurgical Review. 2004;27(1):65-69

23. AL-Bazii, W,J and AL-Bazii, S.J (2014): Histological and physiological study about effect of chronic x-ray exposure on male rabbit brain, Journal of Kerbala University, Vol. 12 No.1 Scientific
24. Pohanka M. (2014): Alzheimer's disease and oxidative stress: a review. Curr Med Chem; 21: 356-364.

25. Gaki GS, Papavassiliou AG.( 2014): Oxidative stress-induced signaling pathways implicated in the pathogenesis of Parkinson's disease. Neuromolecular Med; 16: 217-230.

26. Kevin C. Chan, BEng,Pek-lan Khong, MD, Matthew M. Cheung, BEng,Silun Wang, MPhil, Ke-xia Cai, $\mathrm{PhD}$, and Ed X. Wu, PhD (2009): MRI of Late Microstructural and Metabolic Alterations in Radiation-Induced Brain Injuries, Journal of magnetic resonance imajing 29:1013-1020

27. Annalisa Buffo, Inmaculada Rite, Pratibha Tripathi, Alexandra Lepier, Dilek Colak, Ana-Paula Horn, Tetsuji Mori, and Magdalena Go“" tz (2008) Origin and progeny of reactive gliosis: A source of multipotent cells in the injured brain, PNAS _ March 4, vol. 105 _ no. $9_{-}$3581-3

28. Okada S, et al. (2006) Conditional ablation of Stat3 or Socs 3 discloses a dual role for reactive astrocytes after spinal cord injury. Nat Med 12:829-834.

29. Sofroniew MV (2005) Reactive astrocytes in neural repair and protection. Neuroscientist11:400-407.

30. Reier PJ. (1986): Gliosis following CNS injury, the anatomy of astrocytic scars and their influences on axonal elongation. In: Fedoroff S, Vernadakis A. Astrocytes. New York: Academic Press; pp. 263-324.

31. Eng LF, Yu AC, Lee YL. (1992): Astrocytic response to injury. Prog Brain Res; 94:353-365.

32. Tani M, Glabinski AR, Tuohy VK, Stoler MH, Estes ML, Ransohoff RM. (1996): In situ hybridization analysis of glial fibrillary acidic protein mRNA reveals evidence of biphasic astrocyte activation during acute experimental autoimmune encephalomyelitis. Am J Pathol; 148: 889-896.

33. Struzynska L, Dabrowska Bouta B, Koza K, Sulkowski G. (2007): Inflammation-like glial response in leadexposed immature rat brain. Toxicol Sci ;95:156-162.

34. TOFILON PJ, FIKE JR: The radioresponse of the central nervous system: A dynamic process. Radiat Res 153:357-370, 2000.

35. SCHULTHEISS TE, KUN LE, ANG KK, STEPHENS LC: Radiation response of the central nervous system. Int J Radiat Oncol Biol Phys 31:1093-1112, 1995.

36. Keyeux A, Brucher JM, Bemelmans OD, Charlier AA (1997) Late effects of X irradiation on regulation of cerebral blood flow after whole-brain exposure in rats. Radiat Res 147:621-630

37. Gajdusek CM, Tian H, London S, Zhou D, Rasey J, Mayberg MR (1996) Gamma radiation effect vascular smooth muscle cells in culture. Int J Radiat Oncol Biol Phys 36:821-828 
38. Sarma L, Kesavan PC (1993) Protective effects of vitamins $\mathrm{C}$ and $\mathrm{E}$ against gamma ray induced chromosomal damage in mouse. Int $\mathrm{J}$ Radiat Biol 63:759-764

39. Konopacka M, Widel M, Rzeszowska WR (1998) Modifying effect of vitamins C, E and beta-carotene against gamma-ray induced DNA damage in mouse cells. Mutat Res 417:85-94

40. Fatih S. Erol · Cahide Topsakal · M. Faik Ozveren -Metin Kaplan · Nevin Ilhan · I. Hanifi Ozercan · Oguz G. Yildizv(2004) : Protective effects of melatonin and vitamin $\mathrm{E}$ in brain damage due to gamma radiation, An experimental study, Neurosurg Rev , 27:65-69

41. Uc,üncu“ H, Ertekin MV, Yo“ ru“ k O, Sezen O, Ozkan A, Erdog an F, et al.(2006) : Vitamin E and L-carnitine, separately or in combination, in the prevention of radiation-induced oral mucositis and myelosuppression: a controlled study in a rat model. J Radiat Res; 47:91-102.

42. Mutlu-Tu“ rkog` lu U, Erbil Y, Oztezcan S, Olgac, V, Toker G, Uysal M.( 2000): The effect of selenium and/ or vitamin $\mathrm{E}$ treatments on radiation-induced intestinal injury in rats. Life Sci; 66:1905-1913.

43. Yoshimura M, Kashiba M, Oka J, Sugisawa A, Umegaki K.( 2002): Vitamin E prevents increase in oxidative damage to lipids and DNA in liver of ODS rats given total body X-ray irradiation. Free Radic Res; 36:107-112.

44. Karslioglu I, Ertekin MV, Koc,er I, Taysi S, Sezen O, Gepdiremen A, Balci E.( 2004): Protective role of intramuscularly administered vitamin $\mathrm{E}$ on the levels of lipid peroxidation and the activities of antioxidant enzymes in the lens of rats made cataractous with gamma-irradiation. Eur J Ophthalmol; 14:478-485.

45. Felemovicius I, Bonsack ME, Baptista ML, Delaney JP. (1995): Intestinal radioprotection by vitamin E (alpha-tocopherol). Ann Surg; 222:504-508, discussion 508-510.

46. Konopacka M, Widel M, Rzeszowska-Wolny J. (1998): Modifying effect of vitamins C, E and betacarotene against gamma-ray-induced DNA damagein mouse cells. Mutat Res; 417 (2-3):85-94.

47. Abedi SM, Yarmand F, Motallebnejad M, Seyedmajid M, Moslemi D, Ashrafpour M, Bijani A, Moghadamnia A, Mardanshahi A, Hosseinimehr SJ.(2015 ): Vitamin E protects salivary glands dysfunction induced by ionizing radiation in rats. Arch Oral Biol. Sep;60 (9):1403-9

48. Onem G, Aral E, Enli Y, Oguz EO, Coskun E, Aybek H, Ozcan AV, Sacar M, Bir LS, Baltalarli A, Baycu C.( 2006): Neuroprotective effects of L-carnitine and vitamin $\mathrm{E}$ alone or in combination against ischemiareperfusion injury in rats. J Surg Res. Mar;131(1): 124-30
49. Siu AW, Reiter RJ (1998): The efficacy of vitamin $\mathrm{E}$ and melatonin as antioxidants against lipid peroxidation in rat retinal homogenates. J Pineal Res 24:239-24

50. Behl, C. \& Moosmann, R. (2002): Oxidative nerve cell death in Alzheimer's disease and stroke: antioxidants as neuroprotective compounds. Biol. Chem. 383: 521536.

51. Jagetia G. C. and Ravikiran P.B. (2014); Radioprotective potential of nigella sativa axtract in swiss albino mice exposed to whole body gammaradiation. Altern Integr Med,3:4

52. Reelma Velho-Pereira, A. Kuma , and Aarti G. Jagtap (2012): Radioprotection by Macerated Extract of Nigella sativa in Normal Tissues of Fibrosarcoma Bearing Mice. Indian J Pharm Sci. Sep-Oct; 74(5): 403-414.

53. Seyithan Taysi,Ramazan Memisogullari,Mehmet Koc,Ahmet Taylan Yazici,Murat Aslankurt,Kenan Gumustekin (2008):Melatonin reduces oxidative stress in the rat lens due to radiation-induced oxidative injury. International Journal of Radiation Biology Volume 84 , Issue 10

54. Undeger U., Giray B., Faruk Zorlu A., Kamil Oge and Bacaran N. (2004): Protective effect of melatonin on the ionizing radiation induced DNAdamage in the rat brain. Exper Toxicol path 55(5);379-384

55. Koc M, Buyukokuroglu ME, Taysi S (2002):The effect of melatonin on peripheral blood cells during total body irradiation in rats. Biol Pharm Bull. 2002 May;25(5):656-7.

56. Sener G, Jahovic N, Tosun O, Atasoy BM, Yeğen BC (2003): Melatonin ameliorates ionizing radiationinduced oxidative organ damage in rats. Life Sci. Dec 19;74(5):563-72.

57. Vanazani MC,Iacono RF, Caccuri RL, Berria MI. (2005):Immunohistochemical and morphometric features of astrocyte reactivity versus plaque formation in Alzeheimer's disease.Medicina (B.Aires); 56 (3); 213-218

58. Abdolreza Babaee, Seyed Hassan Eftekhar-Vaghefi , Majid Asadi-shekaari, Nader Shahrokhi, Samereh Dehghani Soltani, Reza Malekpour-Afshar, Mohsen Basiri (2015): Melatonin treatment reduces astrogliosis and apoptosis in rats with traumatic brain injury . Iran J Basic Med sci;18(9):867-872

59. Ahmadiasl N, Shokofeh B, Alireza A. Combination Antioxidant Effect of erythropoietin and melatonin on renal ischemia-reperfusion injury in rats. Iran J Basic Med Sci 2013; 16:1209-1211.

60. WIN DARMANTO, MS, MINORU INOUYE, PHD, YOSHIKO TAKAGISHI, PHD, MASAHARU OGAWA, PHD,KATSUHIKO MIKOSHIBA, MD, 
PHD, AND YOSHIH:ARU MURATA, MD, PHD (2000): Derangement of Purkinje Cells in the Rat Cerebellum Following Prenatal Exposure to X-Irradiation: Decreased Reelin Level Is a Possible Cause Journal of Neuropathology and Experimental Neurology Vol. 59, No. 3, . 251-262

61. Kai Zhou, Martina Boström Carl Joakim Ek, Tao Li (2017): Radiation induces progenitor cell death, microglia activation, and blood-brain barrier damage in the juvenile rat cerebellum. Scientific Reports $7: 46181$.

62. Li Cui, Dwight Pierce, Kim E. Light, Russell B. Melchert, Qiang Fu, K. Sree Kumar, and Martin Hauer-Jensen (2010): Sublethal total body irradiation leads to early cerebellar damage and oxidative stress. Curr Neurovasc Res. May ; 7(2): 125-135

63. Weiss, JF.; Kumar, KS.(1988): Antioxidant mechanisms in radiation injury and radioprotection. In: Chow,CK., editor. Cellular Antioxidant Defense. USA: CRC Press; p. 163-189

64. Manda K, Ueno M, Anzai K. (2008): Melatonin mitigates oxidative damage and apoptosis in mousecerebellum induced by high-LET $56 \mathrm{Fe}$ particle irradiation. J Pineal Res.; 44(2):189-96.

65. Drukarch, B.; Schepens, E.; Stoof, J. C.; Langeveld, C. H.; Van Muiswinkel, F. L.(1998): Astrocyteenhanced neuronal survival is mediated by scavenging of extracellular reactive oxygen species. Free Radic. Biol. Med. 25:217-220.

66. Kunkler, P. E.; Kraig, R. P.(1997): Reactive astrocytosis from excitotoxic injury in hippocampal organ culture parallels that seen in vivo.J. Cereb. Blood Flow Metab. 17:26-43

67. Funegard U, Johansson I, Malmer B, Henriksson $\mathrm{R}$, Ericson T. Can atocopherol and $\beta$ carotene supplementation reduce adverse radiation effects on salivary glands? Eur J Canc 1995;31A:2347-2353.

68. Karim MR, Fujimura S, Kadowaki M. Vitamin E as a novel enhancer ofmacroautophagy in rat hepatocytes and H4-II-E cells. Biochem Biophys Res Commum 2010;394:981-987.

69. Farombi EO, Onyema OO. 9.Monosodium glutamateinduced oxidative damage and genotoxicity in the rat: modulatory role of vitamin $\mathrm{C}$, vitamin $\mathrm{E}$ and quercetin. Hum Exp Toxicol. 2006 May;25(5):251-

70. Yilmaz S, Yilmaz E (2006): Effects of melatonin and vitamin $\mathrm{E}$ on oxidative-antioxidative status in rats exposed to irradiation. Toxicology. 1;222(1-2):1-7.

71. Ahamed M and Siddiqui MK. (2007). Low level lead exposure and oxidative stress: current opinions. Clin Chim Acta 383(1-2): p. 57-64.
72. Kanter, M.(2008). Protective effects of Nigella sativa on the neuronal injury in frontal cortex and brain stem after chronic toluene exposure. Neurochemical Research, 33 (11):. 2241-2249.

73. Kanter, M. (2011) "Protective effects of thymoquinone on the neuronal injury in frontal cortex after chronic toluene exposure," J Mol Histol, 42: 39-46.

74. Cemek M, Enginar H, Karaca T, Unak P. (2006): In vivo radioprotective effects of Nigella sativa $\mathrm{L}$ oil and reduced glutathione against irradiationinduced oxidative injury and number of peripheral blood lymphocytes in rats. Photochem Photobiol.;82(6):1691-6.

75. Sisodia R, Kumari S, Verma RK, Bhatia AL. (2006): Prophylactic role of melatonin against radiation induced damage in mouse cerebellum with special reference to Purkinje cells. J Radiol Prot. ;26(2): 227-34.

76. B. Farhood · N. H. Goradel · K. Mortezaee · N. Khanlarkhani · E. Salehi · M. S. Nashtaei · H. Mirtavoos-mahyari 'E. Motevaseli · D. Shabeeb - A. E. Musa · M. Najafi, (2018); Melatonin as an adjuvant in radiotherapy for radioprotection and radio sensitization, Clinical and Translational Oncology

77. Manda K, Anzai K, Kumari S, Bhatia AL (2007): Melatonin attenuates radiation-induced learning deficit and brain oxidative stress in mice. Acta Neurobiol Exp ;67(1):63-70.

78. Moosmann, B.; Behl, C. (2002): Antioxidants as treatment for neurodegenerative disorders. Expert Opin. Investig. Drugs 11:1407-1435;

79. Reiter, R. J.; Acun a-Castroviejo, D.; Tan, D. X.; Burkhardt, S. (2001): .Free radical-mediated molecular damage. Mechanisms for the protective actions of melatonin in the central nervous system. Ann. N.Y. Acad. Sci. 939:200-215;

80. Cui YF, Ding YQ, Zhang Y, Xu H, Jin W, Liu XL, et al.(2005): Apoptotic characteristics of spleen lymphocyte in mice irradiated by lethal dose and its relationship to the expression of Bax and BclXL proteins. Zhongguo Wei Zhong Bing Ji Jiu Yi Xue.;17(2):109-12.

81. Mohseni M, Mihandoost E, Shirazi A, Sepehrizadeh Z, Bazzaz JT, Ghazi-khansari M. (2012): Melatonin may play a role in modulation of bax and bcl-2 expression levels to protect rat peripheral blood lymphocytes from gamma irradiation-induced apoptosis. Mutat Res. ;738-739:19-27.

82. Jang SS, Kim WD, Park WY.(2009): Melatonin exerts differential actions on X-ray radiation-induced apoptosis in normal mice splenocytes and Jurkat leukemia cells. J Pineal Res.;47(2):147-55. 
83. Reza Fardid, Ashkan Salajegheh, Mohammad Amin Mosleh-Shirazi, Sedigheh Sharifzadeh, Mohammad Ali Okhovat, Masoud Najafi, Abolhasan Rezaeyan, and Akbar Abaszadeh, (2017) : Melatonin Ameliorates The Production of COX-2, iNOS, and The Formation of 8-OHdG in Non-Targeted Lung Tissue after Pelvic Irradiation Cell Journal 19(2):324-331 •
84. GIYASETTIN BAYDAS, RUSSEL J. REITER, ABDULLAH YASAR, MEHMET TUZCU, ISMAIL AKDEMIR, and VIKTOR S. NEDZVETSKII (2003): Melatonin reduces glial reactivity in the hippocampus, cortex and cerebellum of streptozotocin- induced diabetic rats. Free Radical Biology \& Medicine, Vol. 35 , No. 7 , pp. $797-80$ 
الملخص العربى

التاثير الوقائى المحتمل لفيتامين هـ وزيت حبة البركة والميلاتونين ضد التغيرات المبكرة

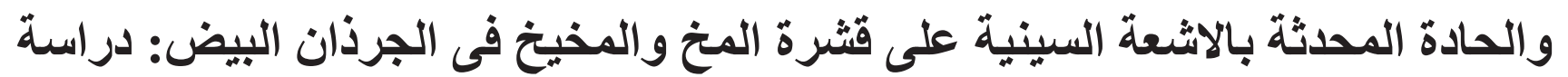
نسيجية وكيمائية نسيجية مناعية

ايمان خليفة احمد، هلى محمد السبد

قسم الهستولوجيا، كلية الطب، جامعة سوهاج

مقدمة: الأضرار الدماغية الناجمة عن الإشعاع شائعة في المرضى الذين يتلقون العلاج الإشعاعي لأورام الرأس و العنق. يمكن أن يكون إعطاء مضادات الأكسدة قبل التعرض للاشعاع مثل فيتامين هـ وزيت حبة البركة و المبلاتونين له دور في الحد من هذه الأضرار.

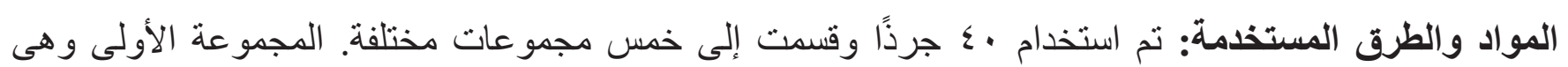
المجموعة الضابطة والتى نت تقسيمها الى ؟ مجمو عات فرعية وتثمل كل منها خمس حيوانات. المجموعة الفرعية

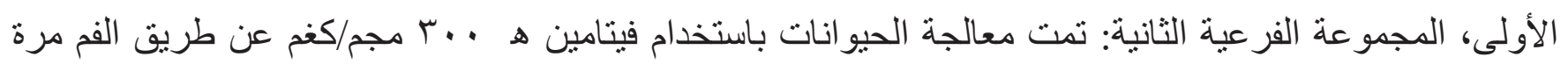
و احدة، المجموعة الفرعية الثالثة تم معالجة الحيوانات باستخدام زيت حبة البركة ا مل / كجم عن طريق الفم مرة

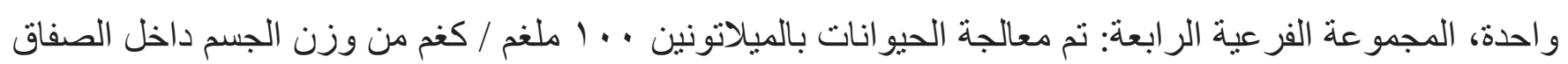

مرة واحدة).

المجمو عة الثانية: تعرض الفئر ان إلى الأشعة السينية (8y 8y لكل الجسم). المجموعة الثالثة: تمت معالجة الحيو انات

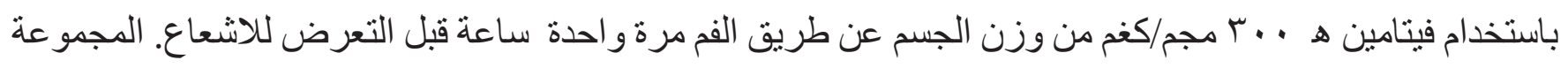

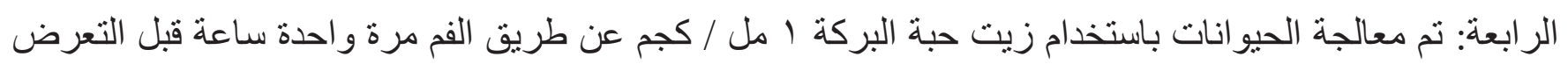
للاشعاع. المجموعة الخامسة: تم معالجة الحيو انات بالميلاتونين .. ملغم / كغم من وزن الجسم (داخل الصفاق مرة و واحدة ساعة قبل التعرض للاشعاع).

النتائج: تسبب الإشعاع فى فقدان للنمط الرقائقي في القشرة الدماغية مع تغيرات تحللية فى الخلايا العصبية. في المخيخ، لوحظ تغير ات تحللية فى خلايا بركنجى. كما تسبب الإشعاع في زيادة ذات دلالة احصائية في عدد الخلايا النجمية الايجابية للبروتين الحامضى الليفى الدبقى في كل من القشرة الدماغية و وقثرة المخيخ الذي انخفض في جميع المجمو عات المعالجة. الاستتتاج: إن استخدام مضادات الأكسدة مثل فيتامين ه، وحبة البركة والميلاتونين يمكن أن يحد من الاثار الضارة للإشعاع على الدماغ و المخيخ. 